\title{
Measurement of basal GH in the diagnosis of acromegaly
}

\author{
Medida do GH basal no diagnóstico de acromegalia
}

Pedro Weslley Rosario'

'Postgraduation Program, Neuroendocrinology Department, Santa Casa de Belo Horizonte, MG, Brazil

Correspondence to:

Pedro Weslley Rosario Programa de Pós-Graduação,

Departamento de

Neuroendocrinologia,

Santa Casa de Belo Horizonte

Av. Francisco Sales, $1111,9^{\circ} \mathrm{D}$

30150-221 - Belo Horizonte, MG Brazil

pedrorosario@globo.com

Received on Sept/2/2010 Accepted on Sept/9/2010
$\mathrm{T}$ he measurement of growth hormone $(\mathrm{GH})$ is fundamental for the diagnosis of acromegaly $(1,2)$. This measurement should be performed using assays that contain standards calibrated against the World Health Organization (WHO) 2nd International Standard (IS) 98/574, with antibodies which essentially recognize the $22-\mathrm{kDa}$ isoform and with results reported as mass unit $(\mu \mathrm{g} / \mathrm{L})$. Classically, GH is measured during a suppression test $(1,2)$, which requires the administration of an oral glucose overload and the collection of five samples at intervals of 30 minutes, with the patient remaining in the laboratory for at least 2 hours. Simplification and cost reduction of this assessment would be interesting, for example, a single morning collection for the measurement of IGF- 1 and GH could be performed. In this respect, a recent consensus suggested that, in the presence of clinical suspicion, the finding of clearly elevated GH and IGF-1 might be sufficient for the diagnosis of acromegaly without the need for a suppression test (1). It now remains to be determined which basal GH values are normally found in normal adults using an assay that meets current international requirements (1). Suppression testing should no longer be required if basal GH above these values associated with elevated IGF- 1 in patients with a suspicion of acromegaly is observed.

To answer this question, samples were collected in the morning after an approximate 10-h fast from apparently healthy volunteers (no diabetes mellitus, anemia, thyroid dysfunction, or renal, hepatic or pituitary disease) who were not using any medications (including anovulatory agents, estrogens or corticosteroids). Pregnant women were excluded. The group consisted of 620 women and 580 men ranging in age from 18 to 70 years, with a body mass index $\geq 18.5$ and $\leq 30 \mathrm{~kg} / \mathrm{m}^{2}$. Premenopausal women were evaluated during the follicular phase of the menstrual cycle. The GH assay used at various clinical analysis laboratories in Brazil was chosen (Immulite, Diagnostic Products Corporation, Los Angeles, CA). The technical characteristics of the assay are known $(3,4)$. For definition of the cut-off, the same criterion as that used for nadir GH $(3,4)$ and applicable based on the non-normal distribution of serum GH [i.e., 97.5 th percentile of the values obtained $(3,4)$ ] was adopted.

Among the 620 women studied, GH ranged from undetectable (in two) to 16.2 $\mu \mathrm{g} / \mathrm{L}$, with a mean of $2.48 \mu \mathrm{g} / \mathrm{L}$, a median of $2.31 \mu \mathrm{g} / \mathrm{L}$, and a value of $9.87 \mu \mathrm{g} / \mathrm{L}$ corresponding to the 97.5 th percentile. In the 580 men studied, GH was undetectable in 12 and the highest value was $6.05 \mu \mathrm{g} / \mathrm{L}$, with a mean of $0.96 \mu \mathrm{g} / \mathrm{L}$ and a median of $0.91 \mu \mathrm{g} / \mathrm{L}$. The value corresponding to the 97.5 th percentile was $4.6 \mu \mathrm{g} / \mathrm{L}$. 
We first emphasize that no previous study has evaluated basal GH levels in as many subjects as the present investigation and that the sample was carefully selected, eliminating conditions known to interfere with GH levels. Furthermore, the assay chosen is the one most widely used in Brazil and meets current international requirements (1). In addition, since peak GH secretion in adults rarely occurs in the morning (5), measurements were performed at that time of the day to reduce the probability of obtaining values as high as those found in acromegalic patients.

The main limitation of basal GH measurement for the diagnosis of acromegaly is its specificity. In the present study, basal GH levels $>4.6 \mu \mathrm{g} / \mathrm{L}$ in men and $>$ $9.87 \mu \mathrm{g} / \mathrm{L}$ in women presented a specificity of $97.5 \%$. It therefore seems reasonable to propose that the observation of levels $\geq 5 \mu \mathrm{g} / \mathrm{L}$ and $10 \mu \mathrm{g} / \mathrm{L}$, respectively, in clinical practice excludes the need for OGTT when associated with elevated IGF-l in patients with a suspicion of acromegaly. Using the same assay, Arafat and cols. (3) reported basal GH levels $>5 \mu \mathrm{g} / \mathrm{L}$ in only $10 \%$ and $>10 \mu \mathrm{g} / \mathrm{L}$ in $<3 \%$ of 213 subjects aged 20 to 76 years, with a predominance of females $(69 \%)$. These cut-off values $(5 \mu \mathrm{g} / \mathrm{L}$ for men and $10 \mu \mathrm{g} / \mathrm{L}$ for women) also show high specificity when $\mathrm{GH}$ is measured with other currently available assays $(3,6-9)$. It is important to note that the specificity of basal GH measurement using the cut-off values cited above is as high as the specificity of nadir GH in the OGTT considering the currently proposed cut-off of $0.4 \mu \mathrm{g} / \mathrm{L}(3,4,6)$.

In conclusion, we suggest that in patients with a suspicion of acromegaly and elevated serum IGF-1, the observation of basal GH levels $\geq 5 \mu \mathrm{g} / \mathrm{L}$ in men and $\geq 10 \mu \mathrm{g} / \mathrm{L}$ in women excludes the need for suppression testing after an oral glucose overload for the diagnosis of acromegaly since these values present a specificity $(97.5 \%)$ as high as that of nadir GH $(3,4,6)$.

Disclosure: no potential conflict of interest relevant to this article was reported.

\section{REFERENCES}

1. Giustina A, Chanson P, Bronstein MD, Klibanski A, Lamberts $S$, Casanueva FF, et al. A consensus on criteria for cure of acromegaly. J Clin Endocrinol Metab. 2010;95:3141-8.

2. Barkan $A$, Bronstein MD, Bruno OD, Cob A, Espinosa-de-los-Monteros AL, Gadelha MR, et al. Management of acromegaly in Latin America: expert panel recommendations. Pituitary. 2010;13:168-75.

3. Arafat AM, Möhlig M, Weickert MO, Perschel FH, Purschwitz J, Spranger J, et al. Growth hormone response during oral glucose tolerance test: the impact of assay method on the estimation of reference values in patients with acromegaly and in healthy controls, and the role of gender, age, and body mass index. J Clin Endocrinol Metab. 2008;93:1254-62.

4. Rosário PW, Furtado MS. Growth hormone after oral glucose overload: revision of reference values in normal subjects. Arq Bras Endocrinol Metabol. 2008;52:1139-44.

5. Melmed S. Medical progress: acromegaly. N Engl J Med. 2006;355:2558-73.

6. Markkanen $\mathrm{H}$, Pekkarinen T, Välimäki MJ, Alfthan $H$, KauppinenMäkelin R, Sane T, et al. Effect of sex and assay method on serum concentrations of growth hormone in patients with acromegaly and in healthy controls. Clin Chem. 2006;52:468-73.

7. Endert $E$, van Rooden M, Fliers E, Prummel MF, Wiersinga WM. Establishment of reference values for endocrine tests-part V: acromegaly. Neth J Med. 2006;64:230-5.

8. Ronchi $C L$, Arosio M, Rizzo E, Lania AG, Beck-Peccoz P, Spada A. Adequacy of current postglucose $\mathrm{GH}$ nadir limit $(<1 \mathrm{microg} / \mathrm{l})$ to define long-lasting remission of acromegalic disease. Clin Endocrinol (Oxf). 2007;66:538-42.

9. Gullu S, Keles H, Delibasi T, Tonyukuk V, Kamel N, Erdogan G. Remission criteria for the follow-up of patients with acromegaly. Eur J Endocrinol. 2004;150:465-71. 